\title{
TGF beta1 and related-Smads contribute to pulmonary metastasis of hepatocellular carcinoma in mice model
}

\author{
Guo-Cai Li ${ }^{1,2}$, Qing-Hai Ye ${ }^{1}$, Qiong-Zhu Dong ${ }^{1}$, Ning Ren ${ }^{1}$, Hu-Liang Jia ${ }^{1}$ and Lun-Xiu Qin ${ }^{1 *}$
}

\begin{abstract}
Background: Recent studies indicate that Transforming Growth Factor beta (TGF $\beta$ ) correlated with pulmonary metastasis of cancers. However, the correlation between TGF $\beta$ and pulmonary metastasis of hepatocellular carcinoma (HCC) is till unknown.

Methods: We detected the in vitro and in vivo expression levels of TGF $\beta 1 /$ Smads by Real-time PCR and Western blot in MHCC97-H and MHCC97-L cell lines, which are HCC cell lines and have higher and lower pulmonary metastatic potential respectively.

Results: TGF $\beta 1$ mRNA level in MHCC97-L tumors were higher than that in MHCC97-H tumors, $(2.81 \pm 1.61$ vs. 1.24 $\pm 0.96, P=0.002)$, TGF $\beta 1$ protein level in MHCC97-L tumors were also higher than that in MHCC97-H tumors $(1.37 \pm 0.95$ vs. $0.32 \pm 0.22, P<0.001)$. In addition, the TGF $\beta 1$ mRNA level positively correlated with pulmonary metastasis, and the relations between TGF $\beta 1$ and Smads were also found $\left(R^{2}=0.12\right.$ and 0.40 , respectively).

Conclusions: Our results suggest that TGF $\beta /$ Smads promote pulmonary metastasis of HCC.
\end{abstract}

Keywords: Hepatocellular carcinoma, Metastasis, Transforming growth factor beta

\section{Background}

Hepatocellular carcinoma (HCC) is one of the most common cancers in the world. The overall five-year survival rate following resection has remained as poor as $35-50 \%$ [1-3]. The extremely poor prognosis of HCC is largely the result of a high rate of recurrence after surgery and of metastasis $[4,5]$. Lung is the most common site for extrahepatic recurrence of HCC. The incidence of pulmonary metastasis after hepatic resection for HCC ranges from $37 \%$ to $58 \%$ [6]. Therefore, to reduce the pulmonary metastasis could ameliorate the prognosis of HCC.

Transforming growth factor beta (TGF $\beta$ ) is a known regulator of epithelial cell, autonomous tumor initiation, progression and metastasis [7-9]. There are three kinds of molecular in TGF $\beta$ family, while, TGF $\beta 1$ is predominantly and importantly expressed in liver cells [10], whereas two other members, TGF $\beta 2$ and TGF $\beta 3$, are present in a little amounts and its roles are even ignored

\footnotetext{
* Correspondence: LX_qin@yahoo.com.cn

'Liver Cancer Institute \& Zhongshan Hospital, Institutes of Biomedical Science, Fudan University, Shanghai, China

Full list of author information is available at the end of the article
}

in many studies [11]. Signaling of TGF $\beta 1$ play a role mainly through Smad proteins [12]. Recently, a report indicates that transient exposure of breast cancer cells to TGF $\beta$ which produced in the primary tumor microenvironment promotes cancer cells to extravagate from blood vessels and entry into the lung by upregulation of the adipokine angiopoietin-like 4 [13].

In HCC, TGF $\beta$ is a useful serologic marker for diagnosis because it shows higher sensitivity than AFP in earlier stage of cancer [14]. In addition, the role of TGF $\beta 1$ in HCC metastasis is emphasized. In a study by Giannelli et al. Laminin-5 (Ln-5) and TGF $\beta 1$ cooperatively induce epithelial mesenchymal transition (EMT) and cancer invasion in HCC [15]. However, although a multitude of studies have presented evidence for TGF $\beta$ changes in HCC tumors, the direction of the changes is not always consistent. In several studies, TGF $\beta 1$ levels are demonstrated to be lower $[16,17]$, while, in other studies, the levels are demonstrated to be higher versus healthy individuals $[18,19]$.

In this study, by comparing the different expression of TGF $\beta /$ Smads in HCC cell lines, we tried to investigate 
the correlation between TGF $\beta /$ Smads levels and potential of pulmonary metastasis in HCC.

\section{Materials and methods Cell lines}

MHCC97-L and MHCC97-H, were human HCC cell lines, and which have a lower and higher metastatic potential respectively. These cell lines were clonally selected from the same parent cell lines, MHCC97, they have an identical genetic background [20,21]. Both cell lines were cultured in high glucose Dulbecco's modified Eagle's medium (H-DMEM, Gibco) and supplemented with $10 \%$ fetal calf serum (Gibco) at $37^{\circ} \mathrm{C}$ in a humidified incubator that contained $5 \% \mathrm{CO}_{2}$.

\section{Samples}

31 samples and observed data were selected randomly from our previous experiment, which were tissues of MHCC97$\mathrm{H}$ models $(\mathrm{n}=20)$ and MHCC97-L models $(\mathrm{n}=11)$. The models were established as follow: $6 \times 10^{6} \mathrm{MHCC} 97-\mathrm{H}$ and $6 \times 10^{6}$ MHCC97-L cells were inoculated subcutaneously into the right side backs of the nude mice (average weight $25 \mathrm{~g})$. After tumor formed, the tumor size was estimated according to the formula: volume $\left(\mathrm{mm}^{3}\right)=0.5 \mathrm{a}^{2} \times \mathrm{b}$, in which "a" is the major diameter of tumor and "b" is the minor diameter perpendicular to the major one [22]. According to our experience, to guarantee enough tumor size and pulmonary metastasis, the MHCC97-L models were feed longer (40days) than MHCC97-H models (35days). In the end of feeding, animals were sacrificed. The tumor and lung tissues were removed and partly cryopreserved in $-70^{\circ} \mathrm{C}$ for real-time PCR analysis, and partly paraffin embedded for immunohistochemstry or $H \& E$ (hematoxylin and eosin) staining.

These experiments were approved by the Shanghai Medical Experimental Animal Care Commission, and were in accordance with the Helsinki Declaration of 1975.

\section{Analysis of pulmonary metastasis}

Each lung tissues were sliced for 20 sections with $5 \mu \mathrm{m}$ in thickness, and $50 \mu \mathrm{m}$ interval between two successive sections. After stained with HE, sections were independently observed under microscopic to evaluate pulmonary metastasis by two pathologists.

\section{RNA extraction and Real-time PCR}

Total RNA of MHCC97-H, MHCC97-L cell lines and tumor tissues were extracted by TRIZOL Reagent (Invitrogen corp, USA) according instruction of the product. Real-time RT-PCR analysis was performed to identify the expression level of TGF $\beta 1$, smad 2 and smad7 by using SYBR Green mix(ToYoBo Co, Japan). The primers were designed by software (premier premier 5.0) as follow: TGF $\beta 1$ (sense $5^{\prime}$ GGCGATACCTCAGCAACCG $3^{\prime}$; antisense, $5^{\prime}$ CTAAGGCGAAAGCCCTCAAT 3'), Smad2 (sense, $5^{\prime}$ TACTACTCTTTCCCTGT $3^{\prime}$; antisense, $5^{\prime}$ TTCTTGTCATTTCTACCG $3^{\prime}$ ), Smad7 (sense, $5^{\prime}$ CAA CCGCAGCAGTTACCC $3^{\prime}$; antisense, $5^{\prime}$ CGAAAGCC TTGATGGAGA $3^{\prime}$ ), $\beta$-actins (sense, $5^{\prime}$-TCGTGCGTG ACATTAAGGAG-3'; antisense, $5^{\prime}$ - ATGCCAGGGTAC ATGGTAAT-3 ${ }^{\prime}$ ). Amplification conditions were: $95^{\circ} \mathrm{C}$ for 9 min, followed by 45 cycles of $95^{\circ} \mathrm{C}$ for $30 \mathrm{~s}, 57^{\circ} \mathrm{C}$ for $30 \mathrm{~s}$ and $72^{\circ} \mathrm{C}$ for $15 \mathrm{~s}$, and followed by an extension at $72^{\circ} \mathrm{C}$ for $5 \mathrm{~min}$. $\beta$-actins was used as a control for the presence of amplifiable cDNA. The mRNA expression level was assessed by $2^{-\Delta \mathrm{Ct}}$ in brief, the Ct value for target gene was subtracted from the $\mathrm{Ct}$ value of $\beta$-actins to yield a $\Delta \mathrm{Ct}$ value. The average $\Delta \mathrm{Ct}$ was calculated for the control group and this value was subtracted from the $\Delta \mathrm{Ct}$ of all other samples (including the control group). This resulted in a $\Delta \Delta \mathrm{Ct}$ value for all samples which was then used to calculate the fold-induction of mRNA expression of target gene using the formula $2^{-\Delta \Delta \mathrm{Ct}}$, as recommended by the manufacturer (Bio-Rad, Hercules, CA, USA). In this study, we used MHCC97-H model samples as control group. The detection about mRNA expression in MHCC97-H and MHCC97-L cell lines was repeated for 10 times.

\section{Protein extraction and western blot analysis}

$1 \times 10^{6}$ MHCC97-H, MHCC97-L cells and parts of freeze tumor sample $(\mathrm{n}=12)$ were lysed in RIPA buffer $(50 \mathrm{mM}$ Tris-HCl pH7.5; 150 mM NaCl; 0.5\% NaDOC; 1\% NP40; $0.1 \%$ SDS) plus protease inhibitors. Protein was extracted by micro centrifugation for 30 minutes, Protein concentration was determined using Bradford Reagent. 20ul equal amount of samples and 10ul markers were run onto 10\% SDS-PAGE gel and electro-transferred onto PVDF membrane using Mini-Genie blotting system (Bio-Rad). The membranes were incubated with primary antibody, Mouse anti-human TGF $\beta 1$ antibody (Chemicon, 1:1000 diluted) and Mouse anti-human $\beta$-actins antibody (Chemicon, 1:2000 diluted), and HRP-conjugated goat antimouse IgG secondary antibody (SIGMA, 1:2000 diluted), The membranes were washed and incubated with $10 \mathrm{ml}$ LumiGLO and exposed to film. The blot bands intensity was quantitatively analyzed using FURI Smart View 2000 software (Shanghai). The ratio of TGF $\beta 1$ to $\beta$-actin bands intensity was assessed.

\section{Cytoimmunochemistry and Immunohistochemistry}

$2 \times 10^{5}$ MHCC97-H and MHCC97-L cell were plated and cultured in six-well plate respectively, when reached to $60 \%$ confluent, the cells were fixed with $100 \%$ methanol, permeabilized with $0.5 \%$ Triton X-100, and sequentially incubated with the primary anti- TGF $\beta 1$ monoclonal antibodies and anti-mouse immunoglobulin (Ig) coupled to Horseradish peroxidase (HRP), then, the cells were 
stained with DAB (3, 3'-diaminobenzidine) and counterstained with hematoxylin. Paraffin-embedded tumor tissues were sliced as $5 \mu \mathrm{m}$ sections in thickness and mounted on glass. Slides were deparaffinated and rehydrated over $10 \mathrm{~min}$ through a graded alcohol series to deionized water; 1\% Antigen Unmasking Solution (Vector Laboratories) and microwaved were used to enhance antigen retrieval; the slide were incubated with anti-TGF $\beta 1$ monoclonal antibodies and HRP-conjugated secondary antibody, and then, stained with DAB.

\section{ELASA}

Total protein of all tumor tissues were extracted as described above. TGF $\beta 1$ protein levels in tumors were determined using the Quantikine TGF $\beta 1$ Immunoassay (R\&D, Minneapolis, MN,USA). The operational approach was performed according to manufacture specification.

\section{Statistical analysis}

Statistical analysis was performed using SPSS 11.5 software (SPSS Inc, USA). The data were analyzed by Students' $t$ test, one-way analysis of variance and covariance analysis. All statistical tests were two-sided; a $\mathrm{P}$ value of less than 0.05 was considered statistically significant.

\section{Results}

The tumor weight and pulmonary metastatic rate

The tumors of MHCC9-H model grew fast than that of MHCC97-L, and especially in early stage of tumor formation, MHCC9-H spent shorter time (days) than MHCC97-L getting to the size of $500 \mathrm{~mm}^{3}(21.93 \pm 3.67$ vs. $30.83 \pm 1.94, \mathrm{P}<0.001$ ) (Figure $1 \mathrm{~A}$ ), however, the growth speed became similar from the size of $500 \mathrm{~mm}^{3}$ to $1500 \mathrm{~mm}^{3} \quad(9.00 \pm 2.69$ vs. $10.83 \pm 1.47, \quad \mathrm{P}=0.14 \quad)$ (Figure 1B). MHCC9-H model had bigger pulmonary metastatic loci than MHCC97-L model (Figure 1C,D). The mean tumor weight $(\mathrm{g})$ in $\mathrm{MHCC} 9-\mathrm{H}$ and MHCC97-L were $1.75 \pm 0.75$ and $1.26 \pm 0.51$, and the pulmonary metastatic rate were $55 \%$ and $36.36 \%$; and the average number of metastatic cell in lung were 119.25 \pm 177.39 and $43.36 \pm 47.80$ respectively (Table 1 ).

The MHCC97-H cells have lower mRNA expression level of TGF $\beta 1$ and Smads than MHCC97-L in vitro and in vivo As shown in Table 2, mRNA levels of TGF $\beta 1$ and Smad2 in MHCC97-H cell line were lower than that of MHCC97-L cell line $(0.18 \pm 0.15$ vs. $0.40 \pm 0.19, \mathrm{P}=0.011$; $0.99 \pm 0.17$ vs. $2.56 \pm 0.66, \mathrm{P}=0.047)$, and TGF $\beta 1$ in MHCC97-H model was also lower than that of MHCC97-L models $(1.24 \pm 0.96$ vs. $2.81 \pm 1.61, \mathrm{P}=0.002)$.
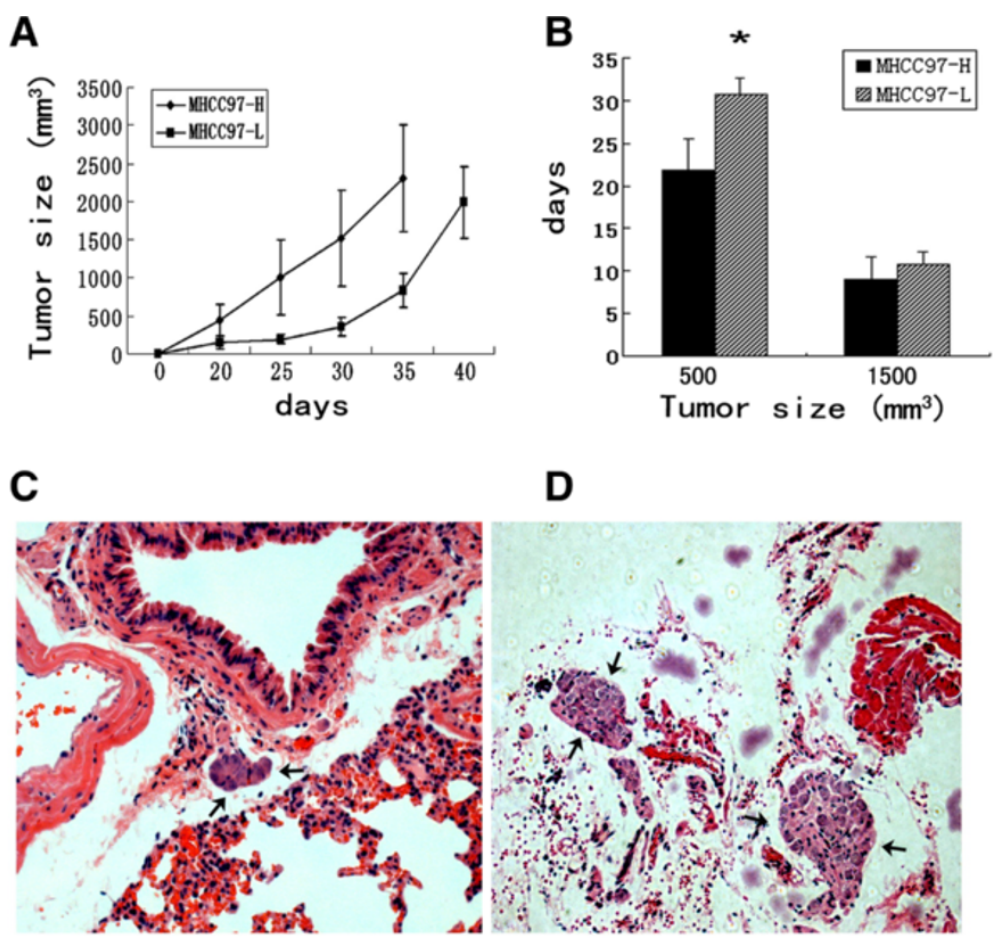

Figure 1 Comparison of Growth and pulmonary metastsis in mice models. A) Growth curve of MHCC97-H and MHCC97-L models; B) Average days which were spent for getting to tumor size. ${ }^{*}$ denoted $\mathrm{P}<0.05$, Error bar represent the standard errors of the mean. C,D) MHCC97-L models (C) had smaller pulmonary metastatic loci than MHCC97-H models (D). Arrows denote metastatic loci. 
Table 1 The tumor weight and pulmonary metastasis rate in different nude mice models of HCC

\begin{tabular}{lllll}
\hline Models & No. of cases & $\begin{array}{l}\text { Tumor weight(g) } \\
\text { (Mean } \pm \text { SD) }\end{array}$ & Metastatic rate & $\begin{array}{l}\text { No. of Metastatic } \\
\text { cells (Mean } \pm \text { SD) }\end{array}$ \\
\hline MHCC97-L & 11 & $1.26 \pm 0.51$ & $36.36 \%(4 / 11)$ & $46.36 \pm 47.80$ \\
\hline MHCC97-H & 20 & $1.75 \pm 0.75$ & $55.00 \%(11 / 20)$ & $119.25 \pm 177.39$ \\
\hline
\end{tabular}

$\mathrm{SD}=$ standard deviation.

Compared with MHCC97-L cells, the expression of TGF $\beta 1$ protein in $\mathrm{MHCC} 97-\mathrm{H}$ was also lower by western blot analysis (Figure 2A), and in mice models, According to quantitative band-intensity analysis of Western blots, the average ratio of TGF $\beta 1$ to $\beta$-actin bands intensity in MHCC97-L models, MHCC97-H models were 0.75 \pm 0.45 and $0.57 \pm 0.37$ (Figure $2 \mathrm{~B}$ ).

By cytoimmunochemistry (Figure $1 \mathrm{Ca}, \mathrm{b}$ ) and immunohistochemistry method (Figure 2Da, b), we found MHCC97-L cell lines and MHCC97-L models have higher expression level of TGF $\beta 1$ than MHCC97-H cell lines and MHCC97-H models.

The TGF $\beta 1$ protein levels correlated with metastasis Compared with MHCC97-H models, MHCC97-L models have a higher TGF $\beta 1$ protein level by ELASA $(0.32 \pm 0.22$ vs. $1.37 \pm 0.95, \mathrm{P}<0.001$ ) (Figure $3 \mathrm{~A}$ ). And in $\mathrm{MHCC} 97-\mathrm{H}$ and MHCC97-L models, we divided all samples (31cases) into two groups according to metastasis, and we found the TGF $\beta 1$ protein level in metastasis group was higher than in none metastasis group by covariance analysis $(0.16 \pm 0.15$ vs. $0.12 \pm 0.10, \mathrm{P}<0.001)$ (Figure $3 \mathrm{~B})$. In addition, in mRNA levels, the relations between TGF $\beta 1$ and Smad2, Smad7 were also found $\left(R^{2}=0.12, P=0.059\right.$ and $\mathrm{R}^{2}=0.40, \mathrm{P}<0.001$, respectively) (Figure $3 \mathrm{C}, \mathrm{D}$ ), but none of them correlated to tumor size.

\section{Discussion}

Although MHCC97-L cell line and MHCC97-H cell line have an identical genetic background, in this study, we observed the expression of TGF $\beta 1$, Smad2 and Smad7 in MHCC97-L cell lines was higher than that in MHCC97-H cell lines both in vitro and in vivo, in addition, MHCC97-L have a slower growth speed in early stage of tumor formation. Our results were in agreement with other documents, which demonstrate TGF $\beta$ can induce apoptosis of human hepatoma cell line in vitro [23], and enhance tumor formation by transfection of an antisense TGF- $\beta 1$ expression vector into cancer cells $[24,25]$. Our results suggest that the basic level of TGF $\beta$ in cell line could affect on its growth, and TGF $\beta 1 /$ Smads play an inhibitory role in the course of tumorigenensis.

We also found the TGF $\beta 1$ protein were positively correlated with pulmonary metastasis in the models, and in mRNA levels, TGF $\beta 1$ correlated with that of Smad 2 and Smad7. Our results were consistent with other studies regarding the association between TGF $\beta 1 /$ Smads and HCC metastasis $[7,15,26]$, and these results support the veiw that TGF $\beta 1 /$ Smads promote pulmonary metastasis of $\mathrm{HCC}$.

The contradict results in this study, inhibitory role in tumorgenesis and promoting role in tumor metastasis, may arise from the dual role of TGF $\beta 1$ in different stage

Table 2 The mRNA expression of TGF $\beta /$ Smads in different cell lines and mice models

\begin{tabular}{|c|c|c|c|c|c|c|}
\hline & \multirow[t]{2}{*}{ Cell line/ Models } & \multirow[t]{2}{*}{ MHCC97H or L } & \multirow[t]{2}{*}{$2-\triangle \triangle \mathrm{Ct}(\mathrm{MEAN} \pm \mathrm{SD})$} & \multicolumn{2}{|l|}{$95 \% \mathrm{Cl}$} & \multirow[t]{2}{*}{$P$ value } \\
\hline & & & & Lower bound & Higher bound & \\
\hline \multirow[t]{4}{*}{ TGF $\beta$} & Cell line & $\mathrm{MHCC} 97 \mathrm{H}$ & $0.18 \pm 0.15$ & 0.07 & 0.29 & \\
\hline & & MHCC97L & $0.40 \pm 0.19$ & 0.26 & 0.52 & $0.011^{\#}$ \\
\hline & Models & MHCC97H & $1.24 \pm 0.96$ & 0.78 & 1.69 & \\
\hline & & MHCC97L & $2.81 \pm 1.61$ & 1.73 & 3.89 & $0.002^{*}$ \\
\hline \multirow[t]{4}{*}{ Smad2 } & Cell line & $\mathrm{MHCC} 97 \mathrm{H}$ & $0.99 \pm 0.17$ & 0.50 & 1.56 & \\
\hline & & MHCC97L & $2.56 \pm 0.66$ & 1.38 & 2.91 & $0.047^{\#}$ \\
\hline & Models & $\mathrm{MHCC97H}$ & $1.18 \pm 0.73$ & 0.84 & 1.53 & \\
\hline & & MHCC97L & $1.52 \pm 0.42$ & 1.23 & 1.80 & $0.172^{*}$ \\
\hline \multirow[t]{4}{*}{ Smad7 } & Cell line & $\mathrm{MHCC} 97 \mathrm{H}$ & $12.36 \pm 1.62$ & 8.32 & 16.40 & \\
\hline & & MHCC97L & $46.98 \pm 30.39$ & -28.52 & 122.48 & $0.187^{\#}$ \\
\hline & Models & $\mathrm{MHCC} 97 \mathrm{H}$ & $1.18 \pm 0.62$ & 0.88 & 1.46 & \\
\hline & & MHCC97L & $1.48 \pm 0.90$ & 0.87 & 2.08 & $0.275^{*}$ \\
\hline
\end{tabular}

Students' $t$ test was used to assess the statistical significance of differences between two groups. 95\%Cl: $95 \%$ Confidence Interval for Mean, SD=standard deviation, " compared with MHCC97-H cell line; * compared with MHCC97-H model. 




of cancer development [27]. It has reported during the early stages of tumor formation, TGF $\beta 1$ acts as a tumor suppressor, inhibiting proliferation and inducing apoptosis of tumor cells. However, during later stages of tumorigenesis, many tumor cells become unresponsive to the growth inhibitory functions of TGF $\beta 1$, and get more motile, more invasive, and more resistant to apoptosis [13]. In addition, TGF $\beta$ can stimulate non-invasive HCC cells to acquire invasive phenotypes [28]. Our results support the view that TGF $\beta 1 /$ Smads play a dual role in the development of HCC. We also observed MHCC97-L cell lines have a higher TGF $\beta 1 /$ Smads levels but a lower metastasis than MHCC97-H cell lines, and both cell lines have an upregulated levels of TGF $\beta 1$ during the course of metastasis. These results reflected the basic levels of TGF $\beta 1$ were not the only factor for metastasis, and highlight that the role of TGF $\beta 1 /$ Smads should be decided in an active course.

The result that TGF $\beta$ correlate with pulmonary metastasis in our study will give a new insight to investigate the metastatic mechanism of HCC. The cells in the tumor tissue communicate through the secretion of growth factors, chemokines, and cytokines during tumor progression, and TGF $\beta$ is unique in its ability to both promote and inhibit tumorigenesis, depending on the cell type it is acting on [29]. Moreover, TGF $\beta 1$ could 

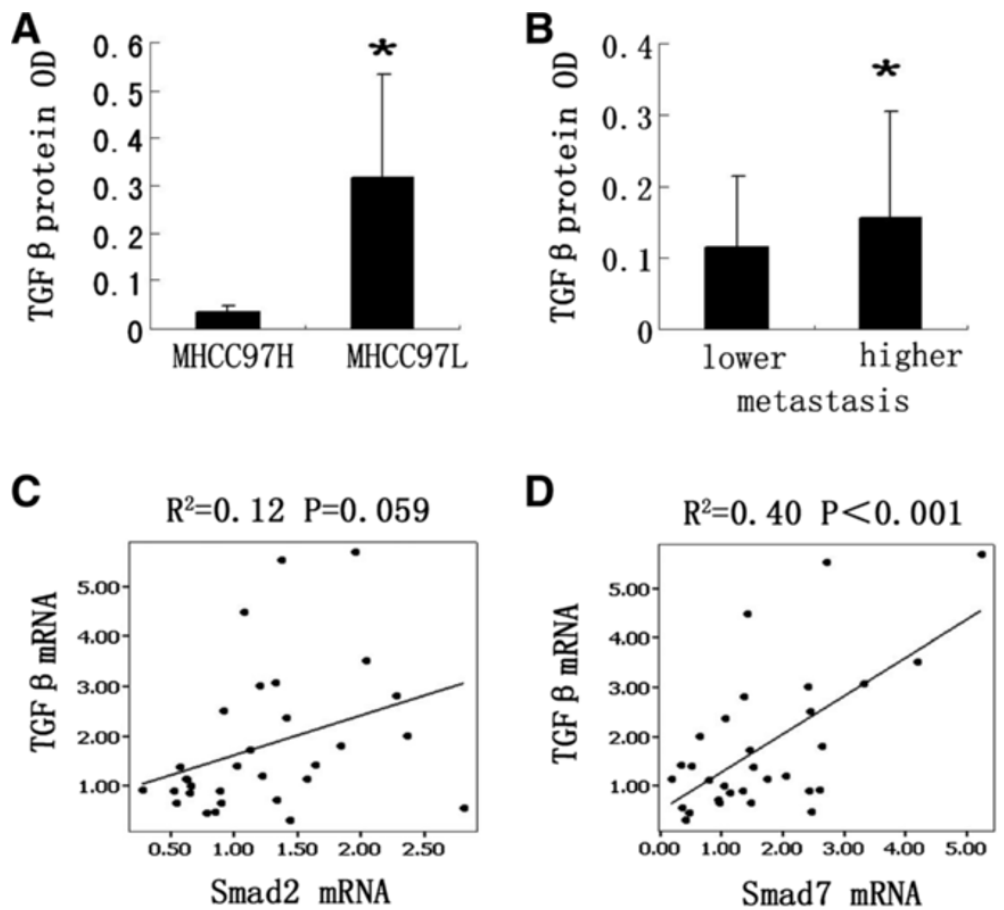

Figure 3 The expression of TGF $\beta$ correlated with pulmonary metastasis. A) MHCC97-L model had a high expression levels than MHCC97-H model by ELASA. * denoted $P<0.05$. B) TGF $\beta 1$ in metastasis group have higher levels than in non- metastasis group. C-D) The correlations between TGF $\beta 1$ mRNA and Smad2, as well as Smad7. Dot denoted the each samples; Lines represent regression line, R: correlation coefficient.

affect various molecular expression, such as $\mathrm{P} 160^{\mathrm{ROCK}}$ [30], Integrin [31] and Matrix Metalloproteinases [32], and all of these molecules relate to HCC invasion.

\section{Conclusions}

Collectively, our results suggest that TGF $\beta 1$ play an important role in the process of tumor growth and pulmonary metastasis of HCC, and the role were timedependent and based on cell type itself. Strategies to modulate expression levels of TGF $\beta 1$ could provide a better approach for the treatment of pulmonary metastasis in HCC.

\section{Abbreviations}

HCC: Hepatocellular carcinoma; PCR: Polymerase chain reaction; DMEM: Dulbecoo's modified Eagle's medium; PBS: Phosphate buffered saline; AFP: Alpha fetal protein.

\section{Competing interests}

The authors declare that they have no competing interests.

\section{Authors' contributions}

$\mathrm{GCL}$ wrote the first draft of the manuscript, performed cell culture and contributed to the experimental design; QHY analyzed data and contributed to writing and editing of the manuscript; DQZ and NR analyzed data; LXQ designed experiments and wrote and revised the manuscript; HLJ performed western blot and wrote and edited the manuscript. All authors read and approved the final manuscript.

\section{Authors' informations}

This work was supported in part by China National Natural Science Foundation for distinguished Young Scholars (30325041), the China National '863' R \& D High-tech Key Project.

\section{Acknowledgements}

We would like to thank Mrs. Qiong Xue, Dong-Mei Gao, Rui-Xia Sun and Jie Chen, Drs. Hai-Ying Zeng, Teng-Fang Zhu and Jun Chen for their help in the animal experiments and cell culture.

\section{Author details}

${ }^{1}$ Liver Cancer Institute \& Zhongshan Hospital, Institutes of Biomedical Science, Fudan University, Shanghai, China. ${ }^{2}$ GaoXin Hospital, Xi'an JiaoTong University, Xi'an, Shanxi Province, China.

Received: 13 August 2012 Accepted: 28 October 2012 Published: 14 November 2012

\section{References}

1. Ono $T$, Yamanoi A, Nazmy E, Assal $O$, Kohno $H$, Nagasue N: Adjuvant chemotherapy after resection of hepatocellular carcinoma causes deterioration of long-term prognosis in cirrhotic patients: meta analysis of three randomized controlled trials. Cancer 2001, 91:2378-2385.

2. Kurokawa Y, Matoba R, Takemasa I, Nagano H, Dono K, Nakamori S, Umeshita K, Sakon M, Ueno N, Oba S, et al: Monden MMolecular-based prediction of early recurrence in hepatocellular carcinoma. $J$ Hepatol 2004, 41:284-291.

3. Lai EC, Fan ST, Lo CM, Chu KM, Liu CL, Wong J: Hepatic resection for hepatocellular carcinoma. An audit of 343 patients. Ann Surg 1995, 221:291-298.

4. Ye QH, Qin $L X$, Forgues $M$, He $P$, Kim JW, Peng AC, Simon R, Li Y, Robles Al, Chen $Y$, et al: Predicting hepatitis $B$ virus-positive metastatic hepatocellular carcinomas using gene expression profiling and supervised machine learning. Nat Med 2003, 9:416-423. 
5. Genda T, Sakamoto M, Ichida T, Asakura H, Hirohashi S: Cell motility mediated by rho and rho-associated protein kinase plays a critical role in intrahepatic metastasis of human hepatocellular carcinoma. Hepatology 1999, 30:1027-1036.

6. Nakamura T, Kimura T, Umehara Y, Suzuki K, Okamoto K, Okumura T, Morizumi S, Kawabata T, Komiyama A: Long-term survival after report resection of pulmonary metastases from hepatocellular carcinoma: report of two cases. Surg Today 2005, 35:890-892.

7. Giannelli G, Fransvea E, Marinosci F, Bergamini C, Colucci S, Schiraldi O, Antonaci S: Transforming growth factor-beta1 triggers hepatocellular carcinoma invasiveness via alpha3beta1 integrin. Am J Pathol 2002, 161:183-193.

8. Lyer S, Wang ZG, Akhtari M, Zhao W, Seth P: TargetingTGFbeta signaling for cancer therapy. Cancer Biol Ther 2005, 4:261-266.

9. Oft M, Peli J, Rudaz C, Schwarz H, Beug H, Reichmann E: TGFbeta1 and HaRas collaborate in modulating the phenotypic plasticity and invasiveness of epithelial tumor cells. Genes Dev 1996, 10:2462-2477.

10. Kinnman N, Andersson U, Hultcrantz C: In situ expression of transforming growth factor-beta 1-3, latent transforming growth factor-beta binding protein and tumor necrosis factor-alpha in liver tissue from patients with chronic hepatitis C. Scand J Gastroenterol 2000, 35:1294-1300.

11. Rubtsov YP, Rudensky AY: TGF $\beta$ signalling in control of T-cell-mediated self-reactivity. Nature Immunol 2007, 7:443-453.

12. Itoh S, Itoh F, Goumans MJ,PTD: Signaling of transforming growth factor-b family members through Smad proteins. Eur J Biochem 2000, 267:6954-6967.

13. Welm AL: TGF $\beta$ primes breast tumor cells for metastasis. Cell 2008 133:27-28.

14. Song BC, Chung YH, Kim JA, Choi WB, Suh DD, Pyo SI, Shin JW, Lee HC, Lee YS, Suh DJ: Transforming growth factor-beta1 as a useful serologic marker of small hepatocellular carcinoma. Cancer 2002, 94:175-180.

15. Giannelli G, Bergamini C, Fransvea E, Sgarra C, Antonaci S: Laminin-5 With Transforming Growth Factor- $\beta 1$ Induces Epithelial to Mesenchymal Transition in Hepatocellular Carcinoma. Gastroenterology 2005, 129:1375-1383.

16. Grasl-Kraupp B, Rossmanith W, Ruttkay-Nedecky B, Mullauer L, Kammerer B, Bursch W, Schulte-Hermann R: Levels of transforming growth factor $\beta$ and transforming growth factor $\beta$ receptors in rat liver during growth, regression by apoptosis and neoplasia. Hepatology 1998, 28:717-726.

17. Jaskiewicz K, Chasen MR: Differential expression of transforming growth factor $\beta$, adhesions molecules and integrins in primary, metastatic liver tumors and in liver cirrhosis. Anticancer Res 1995, 15:559-562.

18. Yuen MF, Norris S, Evans LW, Langley PG, Hughes RD: Transforming growth factor- $\beta 1$, activin and follistatin in patients with hepatocellular carcinoma and patients with alcoholic cirrhosis. Scand J Gastroenterol 2002, 37:233-238.

19. Kim YJ, Lee HS, Im JP, Min BH, Kim HD, Jeong JB, Yoon JH, Kim CY, Kim MS, Kim JY, et al: Association of transforming growth factor- $\beta 1$ gene polymorphisms with a hepatocellular carcinoma risk in patients with chronic hepatitis B virus infection. Exp Mol Med 2003, 35:196-202.

20. Li Y, Tang Y, Ye L, Liu B, Liu K, Chen J, Xue Q: Establishment of a hepatocellular carcinoma cell line with unique metastatic characteristics through in vivo selection and screening for metastasis-related genes through cDNA microarray. J Cancer Res Clin Oncol 2003, 129:43-51.

21. Li Y, Tang ZY, Ye SL, Liu YK, Chen J, Xue Q, Chen J, Gao DM, Bao WH: Establishment of cell clones with different metastatic potential from the metastatic hepatocellular carcinoma cell line MHCC97. World J Gastroenterol 2001, 7:630-636.

22. Carey KD, Garton AJ, Romero MS, Kahler J, Thomson S, Ross S, Park F, Haley JD, Gibson N, Sliwkowski MX: Kinetic analysis of epidermal growth factor receptor somatic mutant proteins shows increased sensitivity to the epidermal growth factor receptor tyrosine kinase inhibitor, erlotinib. Cancer Res 2006, 66:8163-8171.

23. Lin JK, Chou CK: In Vitro apoptosis in the human hepatoma cell line induced by Transforming Growth Factor beta1. Cancer Res 1992, 52:385-388.

24. Wu SP, Sun LZ, Willson JK, Humphrey L, Kerbel R, Brattain MG: Repression of autocrine transforming growth factor beta 1 and beta 2 in quiescent CBS colon carcinoma cells leads to progression of tumorigenic properties. Cell Growth Diff 1993, 4:115-123.
25. Wu SP, Theodorescu D, Kerbel RS, Willson JK, Mulder KM, Humphrey LE, Brattain MG: TGF-beta 1 is an autocrine-negative growth regulator of human colon carcinoma FET cells in vivo as revealed by transfection of an antisense expression vector. J Cell Biol 1992, 116:187-196.

26. Fransvea E, Angelotti U, Antonaci S, Giannelli G: Blocking transforming growth factor-beta up-regulates E-cadherin and reduces migration and invasion of hepatocellular carcinoma cells. Hepatology 2008, 47:1557-1566.

27. Derynck $R$, Akhurst RJ, Balmain A: TGF- $\beta$ signaling in tumor suppression and cancer progression. Nat Genet 2001, 29:117-129.

28. Katabami K, Mizuno H, Sano R, Saito Y, Ogura M, Itoh S, Tsuji T: Transforming growth factor- $\beta 1$ upregulates transcription of a3 integrin gene in hepatocellular carcinoma cells via Ets-transcription factorbinding motif in the promoter region. Clin Exp Metastas 2005, 22:539-548.

29. Littlepage LE, Egeblad M, Werb Z: Coevolution of cancer and stromal cellular responses. Cancer Cell 2005, 7:499-500.

30. Bhowmick NA, Ghiassi M, Aakre M, Brown K, Singh V, Moses HL: TGF-betainduced RhoA and p160ROCK activation is involved in the inhibition of Cdc25A with resultant cell-cycle arrest. PNAS 2003, 100:15548-15553.

31. Wahl SM, Allen JB, Weekst BS HLW, Klotmant PE: Transforming growth factor 1-3 enhances integrin expression and type IV collagenase secretion in human monocytes. PNAS 1993, 90:15548-15553.

32. Li GC, Ye QH, Xue YH, Sun HJ, Zhou HJ, Ren N, Jia HL, Shi J, Wu JC, Dai C, et al: Human mesenchymal stem cells inhibit metastasis of a hepatocellular carcinoma model using the MHCC97-H cell line. Cancer Sci 2010, 101:2546-2553.

doi:10.1186/1756-9966-31-93

Cite this article as: Li et al:: TGF beta1 and related-Smads contribute to pulmonary metastasis of hepatocellular carcinoma in mice model. Journal of Experimental \& Clinical Cancer Research 2012 31:93.

\section{Submit your next manuscript to BioMed Central and take full advantage of:}

- Convenient online submission

- Thorough peer review

- No space constraints or color figure charges

- Immediate publication on acceptance

- Inclusion in PubMed, CAS, Scopus and Google Scholar

- Research which is freely available for redistribution 